\title{
A Study on Health Seeking Behaviour among Married Reproductive Age Group Women in a Rural Area.
}

\author{
Dr.Arun Vijay Paul.R ${ }^{1}$, Dr.Kalidas.P ${ }^{2}$, Dr.Sujatha.K $K^{3}$, Dr.Senthilkumar.S.K ${ }^{4}$, \\ Dr.Sreesupria.Pr ${ }^{5}$ \\ ${ }^{I}$ Associate professor of community medicine, Government Medical college, Coimbatore, India \\ ${ }^{2}$ Professor of community medicine, Government Medical college, Coimbatore, India \\ ${ }^{3,4,5}$ Assistant Professor of community medicine, Government Medical college ,Coimbatore, India
}

\begin{abstract}
Health seeking behaviour among married women of reproductive age group in a rural area was studied by community based cross sectional method. In a sample of 270 women $72.6 \%$ reported taken treatment for their perceived symptoms.Socio-demographic factors like literacy of women, joint family system were significantly associated with the treatment seeking behaviour $(p<0.005)$.Most of the treatment seekers preferred private health facility (44.4\%) and the most common reason (48.50\%) reported by the non treatment group was that the symptoms were not affecting their routine activity. More focus on educating the women, increasing their awareness towards health and highlighting the facilities and schemes in government health sectors will fill the gaps in health seeking behaviour.
\end{abstract}

Keywords: Health seeking, women, reproductive age, rural

\section{Introduction}

The health of women is a key component for determining the progress in meeting the nation's health and development goals. The women health is focused in many programmes and policies of the government like national health policy, national population policy, millennium development goals ,reproductive and child health programme etc[1].If the women is healthy her family is also healthy. One of the indicator that will reflect the health status of women is by determining their health seeking behaviour. Health seeking behaviour refers to those activities undertaken by individuals in response to symptom experience[2] .Exploring the health seeking behaviour is significant in determining cure and mortality rates, and also for planning and providing need based healthcare services to the target population.

According to 2011 census of India $69 \%$ of population reside in rural areas and among them women constitute about $48 \%$ [3]. There is always some diversity in the healthcare needs, utilization and availability of services between the rural and urban areas. Under the national rural health mission (2005) there have been concerted efforts to make women healthcare services accessible and accountable. Literature review shows that there still exist a gap between the available services and health seeking behaviour among women. According to the district level household and facility survey(DLHS-3) only 51\% of women in reproductive age group(15-45 years) had sought care for their health problems[4].Socio-demographic factors, ignorance, fear, perceived quality of service has been found to influence the treatment seeking behaviour[5].This study was conducted in the context of knowing the current trend in health seeking behaviour among married women of reproductive age group and also as there are not many studies done in rural area.

\section{Aims and objectives}

1.To study the pattern of health seeking behaviour among married women of reproductive age group(15-45 years)

2.To analyse the factors that influence the health seeking behaviour among the study group

\section{Methodology}

The study is a cross sectional descriptive type, conducted over a period of two months in the rural field practice areas of the medical college. The sample size was determined based on a prevalence of $46.2 \%$ of treatment seeking behavior reported in a similar setting study[6 ].Allowing an error of $15 \%$ on the prevalence a minimum sample size of 198 was derived. It was decided to survey a sample of 270 women. The sampling method adopted was a WHO cluster type and convenient sampling methods. Thirty subjects each were selected from nine sub centre areas to get a sample of 270 subjects. Married women in reproductive age group (15-45 years) were included in the study, while those who were suffering from chronic diseases and menopausal women were excluded from the study. 
A pretested structured questionnaire was used to collect the necessary data. After getting informed consent from the participants, information regarding the behaviour adopted in response to perceived symptoms for common ailments or gynecological or reproductive system problems within a period of six months preceding the survey were recorded. Common symptoms were cold, cough, fever, headache, tiredness, injuries, neck pain, joint pain, gastric pain. The gynecological or reproductive symptoms enquired were based on as in syndromic approach criteria [7,8] . Socioeconomic status of the study group was determined using modified B.G.Prasad classification [9]

Data was entered in Microsoft excel 2007 and analysed using Epi info 7 software. Data is expressed in percentages and comparison analysis was done using chi square and $\mathrm{Z}$ statistical tests.

\section{Results And Analysis}

The mean age of the study group is 28.6( S.D 5.53) years and the minimum age was 20 years and maximum age was 41 years .Out of 270 women who took part in the survey 196( $72.6 \%$ )sought treatment and $74(27.4 \%)$ did not sought any treatment for their perceived symptoms.

Socio-demographic factors were analysed to find its association with the health seeking behavior (table 1). Literacy level of women ( $p<0.0078)$, type of family $(p<0.0004)$, religion $(p<0.0054)$, and pregnancy $(p<0.03)$ showed significant association. Factors like age, occupation, socioeconomic status, parity and distance of health facility from residence of women, is not significantly associated with treatment seeking behaviour $(p>0.05)$ in the present study.

Table 1. Socio- demographic factors and health seeking in study group.

\begin{tabular}{|c|c|c|c|c|c|}
\hline S.No & Variables & $\begin{array}{l}\text { Sought } \\
\text { Treatment }(N=196)\end{array}$ & $\begin{array}{l}\text { Not Sought } \\
\text { Treatment }(\mathrm{N}=74)\end{array}$ & $\begin{array}{l}\text { Total } \\
(\mathrm{N}=270)\end{array}$ & $\begin{array}{l}\mathbf{P} \\
\text { Value }^{\dagger}\end{array}$ \\
\hline 1 & $\begin{array}{l}\text { Age Group(In } \\
\text { Years) } \\
\text { 20 To 25 } \\
\text { 26 To 35 } \\
\text { 35 To 45 }\end{array}$ & $\begin{array}{l}64(71.1 \%) \\
98(70 \%) \\
34(85 \%)\end{array}$ & $\begin{array}{l}26(28.9 \%) \\
42(30 \%) \\
6(15 \%)\end{array}$ & $\begin{array}{l}90(33.3 \%) \\
140(51.9 \%) \\
40(14.8 \%)\end{array}$ & 0.159 \\
\hline 2 & $\begin{array}{l}\text { Education } \\
\text { Illiterate } \\
\text { School Level } \\
\text { Graduate }\end{array}$ & $\begin{array}{l}29(55.7 \%) \\
108(75 \%) \\
59(79.7 \%)\end{array}$ & $\begin{array}{l}23(44.3 \%) \\
36(25 \%) \\
15(20.3 \%)\end{array}$ & $\begin{array}{l}52(19.2 \%) \\
144(53.3 \%) \\
74(27.5 \%)\end{array}$ & $0.0078^{*}$ \\
\hline 3 & $\begin{array}{l}\text { Occupation } \\
\text { Employed } \\
\text { Unemployed }\end{array}$ & $\begin{array}{l}44(73.3 \%) \\
152(72.3 \%)\end{array}$ & $\begin{array}{l}16(26.7 \%) \\
58(27.7 \%)\end{array}$ & $\begin{array}{l}60(22.2 \%) \\
210(77.3 \%)\end{array}$ & 0.88 \\
\hline 4 & $\begin{array}{l}\text { Type Of Family } \\
\text { Nuclear } \\
\text { Joint }\end{array}$ & $\begin{array}{l}108(65.06 \%) \\
88(84.6 \%)\end{array}$ & $\begin{array}{l}58(34.94 \%) \\
16(15.4 \%)\end{array}$ & $\begin{array}{l}166(61.5 \%) \\
104(38.5 \%)\end{array}$ & $0.0004^{*}$ \\
\hline 5 & $\begin{array}{l}\text { Socioeconomic } \\
\text { Status } \\
\text { Class Upper } \\
\text { Class Middle } \\
\text { Class Lower }\end{array}$ & $\begin{array}{l}20(68.9 \%) \\
86(67.7 \%) \\
90(78.9 \%)\end{array}$ & $\begin{array}{l}9(31.1 \%) \\
41(32.3 \%) \\
24(21.1 \%)\end{array}$ & $\begin{array}{l}29(10.7 \%) \\
127(47 \%) \\
114(42.3 \%)\end{array}$ & 0.133 \\
\hline 6 & $\begin{array}{l}\text { Religion } \\
\text { Hindu } \\
\text { Others }\end{array}$ & $\begin{array}{l}176(75.8 \%) \\
20(52.6 \%)\end{array}$ & $\begin{array}{l}56(24.2 \%) \\
18(47.4 \%)\end{array}$ & $\begin{array}{l}232(86 \%) \\
38(14 \%)\end{array}$ & $0.002^{*}$ \\
\hline 7 & $\begin{array}{l}\text { Children } \\
1 \\
2 \text { Or More }\end{array}$ & $\begin{array}{l}82(69.5 \%) \\
114(75 \%)\end{array}$ & $\begin{array}{c}36(30.5 \%) \\
38(25 \%)\end{array}$ & $\begin{array}{l}118(43.7 \%) \\
152(56.3 \%)\end{array}$ & 0.314 \\
\hline 8 & $\begin{array}{l}\text { Distance Of } \\
\text { Nearest Health } \\
\text { Facility }(\text { In Km) } \\
\text { 3 Or Less } \\
\text { 4 Or More }\end{array}$ & $\begin{array}{l}100(73.5 \%) \\
96(71.6 \%)\end{array}$ & $\begin{array}{l}36(26.5 \%) \\
38(28.4 \%)\end{array}$ & $\begin{array}{l}136(50.4 \%) \\
134(49.6 \%)\end{array}$ & 0.728 \\
\hline 9 & $\begin{array}{l}\text { Antenatal } \\
\text { Yes } \\
\text { No }\end{array}$ & $\begin{array}{l}36(85.7 \%) \\
160(70.1 \%)\end{array}$ & $\begin{array}{l}6(14.3 \%) \\
68(29.9 \%)\end{array}$ & $\begin{array}{c}42(15.6 \%) \\
228(84.4 \%)\end{array}$ & $0.038^{*}$ \\
\hline
\end{tabular}

$†$ Chi square test, *significance level 0.05

Table. 2 represent the preferred choice of health facility approached for types of symptoms perceived by the participants. Among the women who sought treatment, 116(61\%) had symptoms of common ailments 
and $80(41 \%)$ reported perceiving symptoms related to gynecological or reproductive system disorders. The pattern observed is $44.4 \%$ women preferred private health facility,31.2 \% Government sector and $12.7 \%$ from pharmacies, home remedies, traditional healing and alternate medicine respectively. The women who sought care with local trained health worker showed significant association with the symptoms reported $(\mathrm{p}<0.037)$ .There was no association for private, government and other modes of care taken and the type of perceived symptoms $(\mathrm{p}>0.05)$.

Table. 2 Preferred choice of treatment and type of perceived symptoms.

\begin{tabular}{|c|c|c|c|c|}
\hline Healthcare Type & $\begin{array}{l}\text { Symptoms Of } \\
\text { Common } \\
\text { Ailments } \\
(\mathrm{N}=116)\end{array}$ & $\begin{array}{ll}\text { Symptoms } & \text { Of } \\
\text { Gynecological } & \text { Or } \\
\text { Reproductive } & \\
\text { Problems }(\mathrm{N}=80) & \end{array}$ & $\begin{array}{l}\text { Total } \\
(\mathrm{N}=196)\end{array}$ & P Value ${ }^{\dagger}$ \\
\hline Government Hospital & $41(35.34 \%)$ & $20(25 \%)$ & $61(31.2 \%)$ & 0.123 \\
\hline Private Hospital/Doctor & $52(44.8 \%)$ & $35(43.7 \%)$ & $87(44.4 \%)$ & 0.88 \\
\hline $\begin{array}{l}\text { Trained Area Health } \\
\text { Worker }\end{array}$ & $9(7.754 \%)$ & $14(17.5 \%)$ & $23(11.7 \%)$ & $0.037^{*}$ \\
\hline $\begin{array}{l}\text { Others } \\
\text { (Home Remedies, } \\
\text { Pharmacy, Traditional } \\
\text { Methods) }\end{array}$ & $14(12.06 \%)$ & $11(13.75 \%)$ & $25(12.7 \%)$ & 0.779 \\
\hline
\end{tabular}

$\dagger \mathrm{Z}$ test, *significance level 0.05

In exploring the reasons among non treatment group, $48.5 \%$ reported that the symptoms did not affect their routine activity, $30.2 \%$ had family work and time constraints, $10.8 \%$ were not aware of the health facility to visit, $6.7 \%$ told financial reasons, and $3.8 \%$ expressed fear of health examination(Fig.1)

Fig .1. Reasons for not seeking treatment for perceived symptoms

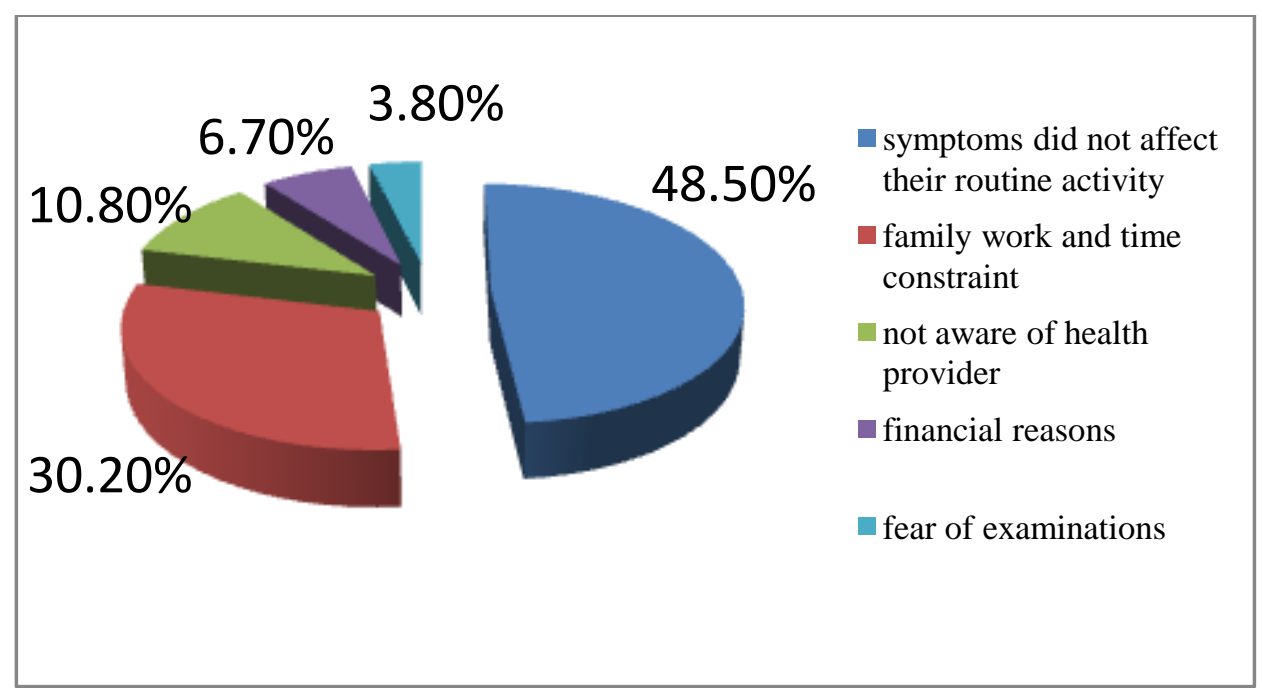

\section{Discussion}

The present study reveals that the $72.6 \%$ of married reproductive age group women approached some treatment form, whereas $27.4 \%$ did not. Treatment seeking is higher when compared to previous studies which shows in the range from $51 \%$ to $55 \%[10,11]$. This can be attributed to increase in awareness among women, apart from geographical variations .Literacy level of women is significantly associated with the health seeking behaviour in this study. More the women is educated more is the treatment seeking behaviour. Similar findings were reported in other studies [12,13]. High literacy in women means more of information on health, development and disease prevention. The study shows that women from joint family seek treatment than those from nuclear families. This correlates with a study done in Tamil Nadu [11].The reason may be the support in family work and advice of other women members to enable the subject to seek care. Joint family still is a common tradition in rural areas. Women belonging to Hindu religion had more treatment seeking behaviour when compared to women of other religion. In the present study women of other religion constituted only 14\%.This study also finds that ante natal women sought treatment more than others, which is a positive approach, as it will promote safe delivery. In a study conducted in rural Karnataka also reports significant antenatal women sought treatment for their morbidity [14].Other aspects like age, social status, occupation,

DOI: 10.9790/0853-1603130811 $\quad$ www.iosrjournals.org $\quad 10 \mid$ Page


parity, distance of health facility does not influence the healthcare seeking behaviour of the subjects in this study. Another study also reported that distance of health facility had no significance for taking treatment among rural women [15].

The most preferred choice of treatment among the study group was private health facility $(44.3 \%)$,followed by government sector(31.2\%). Several other studies have also reported that majority of women sought treatment in private health facility[10,11,13,].It indicates that in spite of free service and facilities available at government health centre's ,women have their own preferences. Also about 14\% of participants chose other modes like pharmacy, home remedies, traditional healers which are unqualified ways. Women with perceived symptoms of gynecological or reproductive tract disorders went to local trained health workers than women reporting common symptoms which is statistically significant $(p<0.010)$.Factors like privacy, familiarity and feeling free for clearing their doubts might be the reason behind this finding.

Most women $(48.5 \%)$ who had not sought treatment reported that the symptoms they perceived were not interfering in their routine activity. Similar finding was reported in a study done at Chennai [6]. Thus it implies that these women are not aware of the benefits of early treatment. As the present study was a community based approach, it may not avoid the reporting bias for self perceived symptoms by the participants.

\section{Conclusion \& recommendation}

The health seeking behaviour of women in rural area is satisfactory, as more than two-third of the study group has sought some treatment. The need for educating the girl child should be focused, which will probably give good results in future. The women should be made aware of the facilities and services available at government sector and also informed on the ill effects in getting treated in other unqualified ways. Capacity building of local health workers to counsel and refer the women with reproductive tract and gynecological symptoms at the appropriate time has to be enhanced. Periodic educational sessions should be conducted for women to stress the benefits of seeking early treatment.

\section{Acknowledgement}

We would like to thank all the participants for giving consent for the study and responding to our questions. We also appreciate the help of field health workers for their assistance during data collection.

\section{References}

[1]. Sunder, L, Textbook of community medicine (New Delhi,:Cbs Publishers \& Distributors, 2011) .67, 138,161,165.

[2]. Keith Tones. Health promotion, Health education \& the public health (oxford university press :oxford textbook of public health, 2004.) 829-863

[3]. Available at http://www.dataforall.org/dashboard/censusinfoindia_pca/[Accessedon18 Mar 2017]

[4]. International Institute for population science (IIPS).district level household survey (DLHS-3), 2007-2008:India.Mumbai;Available at: http://jsk.gov.in/dlhs3/Indiapdf.

[5]. Chauhan.R,Kandan.M, Purty.A., Samuel.A. and Singh. Z, Determinants of health care seeking behavior among rural population of a coastal area in South India, International Journal of Scientific Reports, 1(2)2015, 118

[6]. Anita.S,Daisy.D,Dattagupta.K.K.,Abhinaya..B,Amirthalekha.A.K,Aravind.N,Divakar.R,Dinesh.S,Gayathripriya.K,Reproductive tract infections among women of reproductive age group(15-49 years)-a chennai based study,Journal of dental and medical sciences.15(4)2016,74-78

[7]. Park, K, Park's textbook of preventive and social medicine.(Jabalpur,Bhanot publisher,2015),334-336

[8]. Khan, R. and Khan, Y, Textbook of gynaecology( New Delhi, Cbs Publishers \& Distributors, 2011)31-34

[9]. Mangal A,Kumar.V ,Panesar S,Talwar R,Raut D,Ssingh S,Updated BG Prasad socioeconomic classification,2014:a commentary, Indian J public health 59(1), 2015,42-44

[10]. Abraham.A,Varghese.S,Satheesh.M,Vijayakumar.K,Gopakumar.S,Mendez.AM,Pattern of gynecological morbidity,its factors and health seeking behaviour among reproductive age group women in a rural community of Thiruvananthapuram district,south keral,.Ind J comm. Health26(3),2014,230-237.

[11]. Mani G,Annadurai.K,Danasekaran.R,Healthcare seeking behaviour for symptoms of reproductive tract infections among rural married women in Tamil Nadu-a community based stud,.Online $J$ health allied ses.12(3)2013.available at URL:http://ojhas.org/issue47/2013-3-3.html [Accessed 15 Mar 2017].

[12]. Ravi.R.P,Kulasekara..R.A,Care Seeking Behaviour and Barriers to Accessing Services for Sexual Health Problems among Women in Rural Areas of Tamil Nadu State in India, Journal of Sexually Transmitted Diseases, [online] 2014, 1-8. Available at: http://dx.doi.org/10.1155/2014/292157 [Accessed 18 Mar. 2017].

[13]. Verma, A, Kumar Meena, J. and Banerjee, B., A Comparative Study of Prevalence of RTI/STI Symptoms and Treatment Seeking Behaviour among the Married Women in Urban and Rural Areas of Delhi. International Journal of Reproductive Medicine, [online] 2015,1-8.Available at: http://dx.doi.org/10.1155/2015/563031 [Accessed 18 Mar. 2017].

[14]. Zoe M,Shanthi M,Asha K,Saraswathy G,Ante natal care seeking\&morbidity in rural Karnataka.Asia-pacific population journal,vol.16(2),2001,11-28.

[15]. Rani.M,Bonu.S ,Rural Indian Women's Care-seeking Behavior and Choice of Provider for Gynecological Symptoms. Studies in Family Planning 34(3),2003,173-185. 